\title{
The Nurses No-One Remembers: Looking for Spanish Nurses in Accounts of the Spanish Civil War (1936-1939)
}

\author{
Sioban Nelson \\ University of Toronto, Canada \\ Paola Galbany-Estragués [D \\ University of Vic-Central University of Catalonia, Spain \\ Gloria Gallego-Caminero \\ University of Balearic Islands, Spain
}

\begin{abstract}
Accounts of Spanish nursing and nurses during the Spanish Civil War (1936-1939) that appear in the memoirs and correspondence of International Brigade volunteers, and are subsequently repeated in the secondary literature on the war, give little indication of existence of trained nurses in country. We set out to examine this apparent erasure of the long tradition of skilled nursing in Spain and the invisibility of thousands of Spanish nurses engaged in the war effort. We ask two questions: How can we understand the narrative thrust of the international volunteer accounts and subsequent historiography? And what was the state of nursing in Spain on the Republican side during the war as presented by Spanish participants and historians? We put the case that the narrative erasure of Spanish professional nursing prior to the Civil War was the result of the politicization of nursing under the Second Republic, its repression and reengineering under the Franco dictatorship, and the subsequent national policy of "oblivion" or forgetting that dominated the country during the transition to democracy. This policy silenced the stories of veteran nurses and prevented an examination of the impact of the Civil War on the Spanish nursing profession.
\end{abstract}


"We are the nurses no-one remembers" lamented Ana Pibernat in her memoirs of the Spanish Civil War (SCW; 1936-1939). ${ }^{1}$ The conventional view of nursing in Spain during the war, espoused by the International Brigade (IB) volunteers in their memoirs and correspondence, and repeated in the secondary literature on the war all support Pibernat's contention, giving little indication of the existence of trained nurses in the country and even going so far as to declare them non existent. This observation, and its constant repetition, caused us to wonder at the apparent erasure of the centuries of skilled nursing in Spain and the thousands of Spanish nurses engaged in the war effort on both sides.

In what follows we examine these primary and secondary accounts of Spanish nursing by English language authors and attempt to understand the narrative construction of nursing in Spain. At the same time, we provide a counter-narrative of Spanish nursing on the Republican side, based on Spanish primary sources and secondary scholarship on the topic. We ask two questions: How can we understand the narrative thrust of the international volunteer accounts and subsequent historiography? And what was the state of nursing in Spain on the Republican side during the war as presented by Spanish participants and historians?

The story of La Guerra Civil Española, the SCW remains a deeply wounding and divisive episode in Spanish history. The war began on the 17th of July 1936 with a failed military coup d'etat in the Spanish Protectorate in Morocco. It ended with the defeat of Republican (Government) forces 3 years later, tearing apart regions, institutions, communities, and families. No part of society was immune from the brutal upheaval and deep divisions it left in its wake. ${ }^{2}$ Moreover, under the Dictadura of the victorious Francisco Franco, who led the country from the end of the war in 1939 till his death in 1975, it was forbidden to publish on and dangerous to speak openly about the events of those 3 years. During the transition to democracy in the post-Franco era, the Pact of Oblivion continued this imposed silence under the goal of national reconciliation. Thus, in Spain, the question of the war, its atrocities, and its aftermath remains one of great contention as the nation continues to deal with the challenge of remembering. ${ }^{3}$

The Second Spanish Republic (1931-1939) was a progressive government with a radical agenda that sought the reform of the country's most powerful institutions. It implemented major changes to the military and abolished many of the long-held privileges of the Catholic Church. ${ }^{4}$ It promoted regional autonomy and agrarian reform, introduced equal rights for women, including the right to education, civil marriage, consensual divorce, maternity insurance, and even abortion (although the latter was never implemented). ${ }^{5}$ It also initiated major reforms to public health, nursing education, and nursing services. 
This broad program of reform was seen as a direct threat to the nation's powerful conservative forces: the landlords, the Catholic Church, and the army, all of which coalesced around the nationalist or rebel forces opposing the Republic. ${ }^{6}$

In the mid-1930s, Europe was gripped by a series of crises as radical and reformist governments fell to right-wing and fascist regimes. In Portugal, Italy, and Germany, right-wing governments imprisoned their critics, attacked democratic institutions and increased surveillance of leftists and Jewish citizens. Meanwhile, France's fragile leftist government had to deal with powerful right-wing forces, while the British government pursued its disastrous appeasement stance against Hitler. Both countries failed to support the embattled Republic of Spain. Beyond Europe, the militaristic regime of Japan was growing in strength, and the home-grown fascist movements in the United States and elsewhere were becoming emboldened. Fear of Bolshevism set the tone for international relations in the west and the fact that the Spanish government's only allies were the communist governments of Mexico and Russia heightened the diplomatic tensions. For pro-democratic and leftist individuals, it was apparent that the world was on the brink of a descent into fascism.

Despite the recalcitrant positions taken by their respective governments, pro-democratic and leftist organizations and trade unionists around the world enthusiastically recruited volunteers for Spain to defend the embattled Republican government from the attack of Nationalist forces. The volunteers responded in their thousands, ${ }^{7}$ and the resulting IB threw its weight behind the coalition of anarchists, communists, and republican forces that constituted the Republican side. Overall approximately 700,000 people fought on the Republican side in the war. This figure includes the 35,000 foreigners from 53 countries who served in the IBs, among whom were hundreds of nurses.

The international nurses who went to Spain, with only a handful of exceptions, volunteered on the side of the Republic. It is not possible to determine exactly how many nurses came. The highest estimate comes from Oscar Telge, a Bulgarian major who was head of the International Health Service. In 1937, he notes there were "more than 240 doctors, 600 nurses (men and women) and 650 orderlies working for our Organization." ${ }^{\circ}$ A more conservative number of 203 appeared on a 1937 military document listing source countries but no names of individual nurses. ${ }^{9}$

As part of a separate and on-going project that has been published in Spanish and presented in English, we undertook to learn more about the nurses who volunteered in Spain. We examined the vast primary and secondary literature on the SCW and the IBs looking for references to nurses, nursing, or hospital work. ${ }^{10}$ Our review included English, Spanish, French, Catalan, Italian, and Portuguese literature between 1936 and 2018 inclusive. We identified references to nursing in the biographies, memoirs, ${ }^{11}$ journalist correspondence, 
and testimonies from wounded combatants and from health professionals and workers, such as physicians, orderlies, ambulance drivers, and laboratory technicians. ${ }^{12}$

From our research, we believe the actual number is closer to Telge's estimate. To date, we have identified 342 nurses from 40 countries out of what we believe to be the approximately 600 nurses who came to Spain to volunteer during the War. About half of these nurses were English speaking, many of whom come from leftist and or Jewish background. Of the remainder, women came for all across Europe, from Iceland to Austria, again a significant number appear to have been Jewish. We plan to publish these results in a separate paper.

One of the surprising findings of our review of the primary and secondary source material on nursing during the Civil War was the existence of a consistent series of observations on the state of Spanish hospitals and Spanish nurses. These observations typically comment on the absence of a nursing profession in Spain. As there are limited sources that describe Spanish nurses or the state of Spanish nursing, those sources that do exist have perhaps received undue authority in subsequent scholarship on the war. For instance, one highprofile observation comes from the recollections of volunteer soldier Eric Blair (George Orwell):

Apparently there was no supply of trained nurses in Spain, perhaps because before the war this work was done chiefly by nuns. I have no complaint against the Spanish nurses, they always treated me with the greatest kindness, but there is no doubt they were terribly ignorant. ${ }^{13}$

Orwell's observation echoes that of other volunteers who claimed that Spain had no real trained nurses. Annie Murray, Scottish volunteer nurse later recalled: "They used nuns. So, these little Spanish girls only had about 3 months training. But they were very keen and very good for the time they had trained." 14

The most well-known work on IB nurses and nursing in Spain during the war is that of British historian Angela Jackson whose pioneering work on British women volunteers and her subsequent biography of English IB nurse, Patience Darton, were published in 2002 and 2014 respectively. Over her long and active life, Darton had become the authoritative voice on the standard of Spanish nursing, medicine, and hospitals:

Standards of Hygiene and asepsis were low at that time in Spain, and there was no tradition of nursing training comparable with that in Britain . . nursing care of the patients was generally carried out by other family members or by nuns. ${ }^{15}$ 


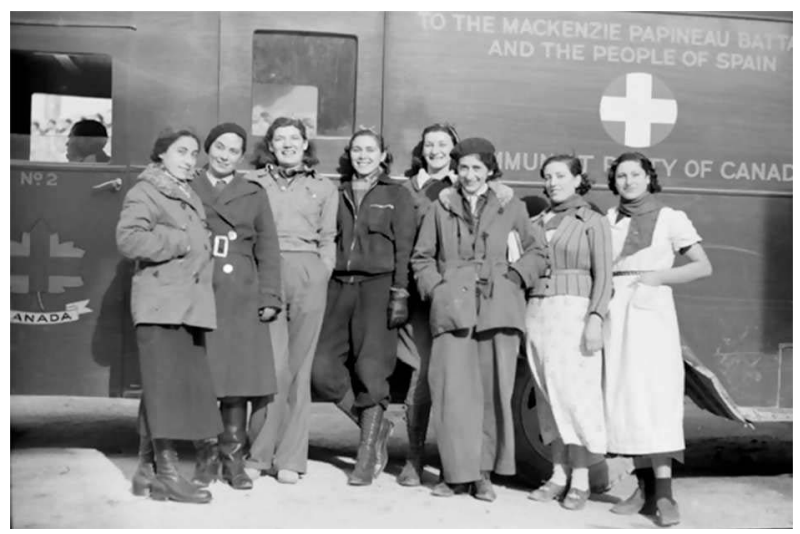

Figure 1. American nurses in front of an ambulance donated by the Communist Party of Canada. Left to right: Rose Weiner, Leonora (Nora) Temple, Toby Jensky, Anna Taft, Sara Goldblatt, Selma Chadwich, and Andrea y Leoncia (Spanish girls). Probably Alcorisa (Teruel). Aragon Front, January 1938. Unknown photographer (Reprinted permission, Archives of Marx Memorial Library, London).

IB nurse Ruth Wilson Epstein's Radio Madrid Broadcast to the United States on January 10,1938, describes the challenging situation that faced the Republican side and the Brigadist hospitals. She speaks about the improvised classroom she established for local illiterate chicas who she taught rudimentary nursing in what she calls the region's "first nursing school" (see Figure 1).

Jackson reports on Darton's observations concerning the modesty of the Spanish nurses, how they were unwilling to wash male patients ${ }^{17}$ and the fact that "it wasn't a good thing for a Spanish girl of any sort, to go and work in a hospital with men." She presents Darton's picture of backward squalid hospitals and ignorant Spanish doctors and nurses (such as the physician who tried to prevent Darton from washing her British typhoid patient). ${ }^{18}$ Given the observations found in eyewitness accounts, it is no surprise that the secondary literature builds on this theme. In 1986 Fryth describes the situation as the following:

There were some very good hospitals, especially in Republican-held Madrid and Barcelona, but nursing services were scanty; hospitals were run by nuns and patients were generally nursed by their own families, who moved in with them, as in the days of the Crimean War. Standards of hygiene, as the British nurses were to discover, were sometimes horrifying. ${ }^{19}$

And in the repetition, the myth grows stronger. In 2013, Linda Palfreeman, in her book Aristocrats, Adventurers and Ambulances describes nurses as a rarity in Spain with care relying on family members. 
At the outbreak of Civil War Spain could boast some excellent hospitals, especially in Madrid and Barcelona, but they were run by nuns and other assistants with very little professional training. Expert nursing care was rarity and patients had to be cared for by members of their own family. ${ }^{20}$

There is no question as to the validity of the observations and experiences of the eye witness accounts of nursing during the war. What is interesting, however, is the conclusion they draw from these observations, and secondly, how it is that they miss so much of the picture. The descriptions by volunteers and repeated by subsequent British historians on the lack of skill of Spanish nurses and the backwardness of Spanish hospitals were based on several assumptions: first that the nursing care of religious sisters or nuns was the equivalent of poor nursing. Second, that knowledge of hospital management and asepsis and hygiene were entirely lacking in the country. Third, that professional secular nursing did not exist in Spain. Let us take these three points in turn.

First, it is important to understand that the Republican or Government side of the Civil War was characterized by extreme anticlericalism (particularly in Barcelona and Andalusia). The Catholic Church was hostile to the secular reforms implemented by the Republic and was a key supporter of the Nationalist rebels. In this context, the Republican view of religious nurses was generally unsympathetic.

Moreover, the dismissal of nursing by religious nurses as antithetical to high-quality nursing is a common categorical error made by nursing and general historians alike. In fact, nursing by religious women and men has a long and distinguished history in Spain. ${ }^{21}$ While not all religious orders were known for their commitment to nursing, nor for their leadership in running the best hospitals, the truly excellent hospitals in Madrid and Barcelona specifically referred to by Fryth and others were operated by nursing sisterhoods. Far from being backward, these institutions were the home base of many of the medical and surgical innovators. ${ }^{22}$

The major problem with the Spanish reliance on religious nurses was that the anti-clerical sentiments of the pro-government side of the conflict meant that the sisters overwhelmingly (but not entirely) abandoned their posts and fled to the nationalist side at the onset of the conflict. ${ }^{23}$ Thus the standard of nursing care and hospital management observed by members of the IBs was Spanish nursing without a key element of its workforce - religious nurses. Brigadists drew their own conclusions from this observation deciding that Spanish nursing was backward and lacking in professionalism, a comparison that reflected well on British and American nurses. 


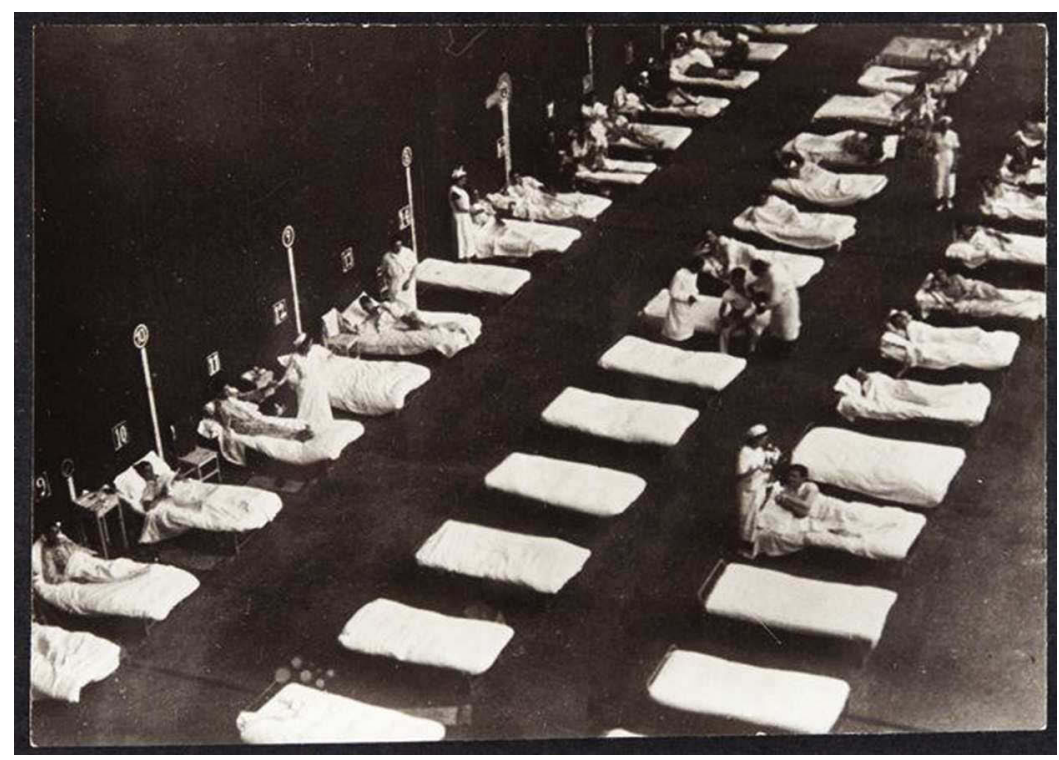

Figure 2. Wounded assisted by civilian nurses at the Provisional Blood Hospital installed on the Fronton of Recoletos by the Libertarian Athenian of Delicias of CNT (Workers National Confederation). Madrid, 1936-1937. Reprinted with the permission of the National Library of Spain.

The second issue concerning poor hospital management and lack of hygiene or knowledge of asepsis arises from a similar lack of contextual understanding. It was not until later in the war that Republican forces possessed a formal medical unit. The military (with few exceptions) supported the Nationalist cause and the medical organization and equipment went to that side, as did religious nurses fleeing anti-clerical forces. Therefore the Republicans, including the volunteer brigades, took some time to put into place their medical infrastructure, both personnel, and equipment (see Figure 2).

There are many accounts of the appalling conditions facing the medical and nursing volunteers when they arrived, whether it was setting up a hospital in a filthy barn, or a sports stadium taking over an overwhelmed improvised hospital or one captured from the nationalist side. In each instance, these stories become a vehicle to tell of the scrubbing and hard work, the improvising with makeshift or antiquated equipment, the bartering for food and water from the local mayor and so forth. In the case of the hospital changing hands, there were often outraged stories of infections and filth, often at the hands of sisters. ${ }^{24}$ 
These Republican stories against religious nurses warrant scrutiny. The evidence of callous and poor nursing by religious nurses witnessed by volunteers is very hard to interpret. It is difficult to know whether the sisters were in fact nurses, or merely volunteers. Thus, the lack of knowledge concerning hygiene or wound care may represent unskilled nursing rather than religious nursing. Without more information, the assumptions drawn by the IB volunteers may have merely been confirming their biases rather than offering conclusive evidence on the backwardness of Spanish nursing and hospital care. One counter story comes from the biographical account of Manuel Álvarez who as a youth was wounded in the war. He later searched for the Canadian volunteer who saved his life. His first-person account is in stark contrast to that offered by so many IB accounts.

Since 1938, whether as a patient or as a visitor, I have known many hospitals around the world, but I still consider the one in Vilanova y la Geltrú the best of all, it was governed by nuns, all of them competent. In the advent of the Revolution, they replaced their habits with nurse uniforms, civil people had replaced the nuns in the administration of the hospital, but in practice, the organization of the hospital continued to unfold very much like a convent, with the mother superior as Director of the institution, the assistance was unbeatable, the nutrition excellent, the atmosphere was saturated by the pious courtesy of those nuns, the whole building was magnificent: high ceiling rooms, large windows opening into a flowered garden. ${ }^{25}$

The first-person accounts of appalling conditions underline the vital role of volunteer nurses in the IB narratives, serving a critical propaganda function back home. In these foreigners' narratives for foreign readers, Spanish nurses are relegated to minor supportive roles of wonderful but ignorant local "chicas" or girls, whom IB nurses trained in basic nursing over the course of the conflict. In one of the few papers that looks at Spanish nurses and nursing during the Civil War, Isabel Anton-Solanas, Ann Wakefield, and Christine Hallett ${ }^{26}$ undertook an analysis of the published accounts by IB nurses to explore the relationship between Spanish and IB nurses. They found sparse evidence of contact between IB nurses and trained Spanish nurses. Anton-Solanas and colleagues were primarily interested in whether the IB nurses had a lasting impact on Spanish nursing, but it is not a question they are able to resolve. In a somewhat solipsistic argument they claim that: "the fact that the international nurses openly acknowledged both the general evolution of Spanish nursing and the personal development of the Spanish women they had trained reveals a qualitative change in nursing services as the war evolved." They conclude that, despite the lack of supportive evidence, "the IB played their part in shaping and advancing Spanish nursing through their work and example." 27 
We fundamentally diverge from the arguments of Anton-Solanas and colleagues. Although we agree that the IB nurses infrequently encountered skilled Spanish nurses, we disagree as to the conclusions that may be drawn from this fact. The IB forces of 35,000 constituted only approximately 5\% of the forces fighting on the Republic side during the war. That leaves $95 \%$ of the Republican forces and $100 \%$ of the rebel or Francoist forces who were served by Spanish medical and nursing teams. Furthermore, the cities, towns, and villages of Spain continued to require the care of doctors, practicantes, nurses, and midwives and, amid the desperation and chaos of war, that care continued as best it could. ${ }^{28}$ In order to examine the story of Spanish nursing missing from the first person and secondary accounts of international volunteers, we will look at Spanish nursing in three parts: before the Civil War, during the war, and its aftermath.

\section{Part 1: Spanish Nursing Before the Civil War}

It can be safely assumed foreign nurses knew little of the system of training, different types of licenses and programs that existed within Spain, nor did they understand the complex role of male and female nursing orders in the country (see Table 1, Official designations of nurses in Spain). Spanish nursing wasa particular mixture of highly skilled and professional religious and secular nurses, with state-based oversight for licensure that had been in place for centuries. ${ }^{29}$

In fact, Spain had conducted programs of education and training overseen by the national government since the 16th century, along with national examinations of men and women nurses of the different categories (midwives, bleeders, practicantes, and nurses). The practicante was a 19th-century initiative and can be best described as a medical assistant with a highly independent practice; these individuals tended to be male. Carmen Domínguez-Alcón identified at least 67 manuals of instruction on nursing care in Spanish were published in the 19th century ${ }^{30}$ with a further 59 instruction manuals were published between 1900 and $1936 .{ }^{31}$ The training of practicantes and midwives was continuously and officially regulated in Spain since 1857 with the implementation of the Moyano Law, which regulated education across the country, the law that oversaw the modernization of the Spanish education system in the mid-19th century. Even after the SCW, they were still appointed to villages and cities as municipal employees with an obligation to provide free of services to the poor. ${ }^{32}$ 
TABLE 1. Brief History of Nursing Licensing in Spain XIX to the Present Day

\begin{tabular}{|c|c|}
\hline Designation & Official Rules \\
\hline Matrona (Midwife) & Both designations appear in the Moyano \\
\hline Practicante (Practitioner) & $\begin{array}{l}\text { Law, or Law of Public Instruction edict } \\
\text { (1857). This law replaced previous } \\
\text { regulations concerning programs and } \\
\text { exams for midwives, minor surgeons, or } \\
\text { "bloodletters," and so forth. It introduced } \\
\text { a } 2 \text { year program of four semesters in } \\
\text { authorized centers with exams overseen } \\
\text { by medical schools. Subsequent official } \\
\text { decrees continued to regulate the studies } \\
\text { and practice of these professions in } 1861 \text {, } \\
1888 \text {, and } 1904 \text {. }\end{array}$ \\
\hline Enfermera (Nurse) & $\begin{array}{l}\text { Introduced in } 1915 \text { as an official } \\
\text { designation in line with midwives and } \\
\text { practicantes. Included religious and } \\
\text { secular nurses. }\end{array}$ \\
\hline ATS (Technical Health & Decree of 4th December 1953, (BOE of \\
\hline Assistant) & $\begin{array}{l}\text { 29th of December 1953) The decree } \\
\text { brought together former midwives, } \\
\text { practicantes, and nurses under a single } \\
\text { designation: Technical Health Assistant. } \\
3 \text { years of study. Graduates could } \\
\text { continue their studies in midwifery and } \\
\text { other specialties. Membership of the } \\
\text { College of Nursing required to work as a } \\
\text { nurse. }\end{array}$ \\
\hline Diplomado en enfermeria & On July 23, 1977 (BOE of August 22, \\
\hline (Diploma in Nursing) & $\begin{array}{l}\text { 1977), the Technical Health Assistant } \\
\text { schools were transformed into university } \\
\text { schools of nursing. The new designation } \\
\text { was Diploma in Nursing ( } 3 \text { years study). } \\
\text { Applicants to Nursing required the same } \\
\text { requirements for University admission as } \\
\text { other studies (medicine, architecture, } \\
\text { pharmacy, etc.). }\end{array}$ \\
\hline
\end{tabular}


TABLE 1. Brief History of Nursing Licensing in Spain XIX to the Present Day (Continued)

\begin{tabular}{ll}
\hline Designation & Official Rules \\
\hline Técnico en Cuidados & Commencing in 1996 auxiliary nurses \\
Auxiliares de Enfermeria & were formalized in Spain. These programs \\
(Technician in auxiliary & are not university based and do not lead \\
nursing care) & to enrollment in the Professionals \\
& Associations of Nurses (colegios \\
& profesionales de enfermeria) in each capital \\
of province. The Auxiliares de enfermeria & support the work of the diplomate \\
& College nurses. \\
& From 2009, degree entry to practice in \\
Grado en enfermeria & Spain. The Grado en enfermeria entails 4 \\
(Nursing Graduate) & years of study in conformity with nursing \\
& programs in other European countries. \\
\hline
\end{tabular}

Note. Registration with the regional college or professional association (colegios provinciales de enfermeria) was compulsory to work as a nurse. Religious nurses were not required under law to qualify in the smae manner until 1953, although many in fact conducted nursing schools and completed the same programs of study.

Religious nurses did not tend to undertake training as practicantes and were forbidden until the mid-20th century to be involved in midwifery practice. Therefore their training tended to take place in their hospitals and, before 1915, in Italy. When training for nurses was regularized, along with midwives and practicantes in 1915, religious sisters undertook the same preparation as secular nurses.

Over the course of the 19th and 20th century, Spanish nursing continued to evolve its licensure processes and increased the numbers of non-religious nursing schools in the country. Although there is no single data source for the number of trained nurses in Spain prior to the war, one can get a sense of how many trained secular nurses there were at the outbreak of the war looking at the various training programs and numbers of graduates sitting national examinations. 18 years before the Civil War, in 1917, in addition to long-established schools, the Spanish Red Cross, or Cruz Roja, established 32 schools of nurses in Spain. The Schools developed their own manuals for theoretical and practical courses. In 1921 the Cruz Roja had 30 training centers of voluntary nurses unpaid, who had trained to 729 volunteers nurses. ${ }^{33}$ (See Table 2 for a summary of the Leading Nursing Schools in Spain prior to the Civil War.)

By 1931 the number of women receiving instruction from Cruz Roja was $526 .{ }^{34}$ That same year, 366 nurses took the first State examination of nurses at 
TABLE 2. Principal Schools of Nursing before the Spanish Civil War

\begin{tabular}{|c|c|c|c|}
\hline Active & City & Name & Observations \\
\hline $1896-1936$ & Madrid & $\begin{array}{l}\text { Escuela Santa Isabel de } \\
\text { Hungria en el Instituto de } \\
\text { Terapéutica Operatoria (St. } \\
\text { Isabel of Hungary School at } \\
\text { the Institute of Surgical } \\
\text { Therapy). The candidates } \\
\text { lived in and were subject to } \\
\text { strict oversight over the } 3 \\
\text { years. }\end{array}$ & $\begin{array}{l}\text { Destroyed during } \\
\text { the SCW }\end{array}$ \\
\hline $\begin{array}{l}\text { 1914-up to } \\
\text { day }\end{array}$ & Madrid & $\begin{array}{l}\text { Escuela de enfermeras de la } \\
\text { Cruz Roja (Red Cross Nurses } \\
\text { School). They taught both } \\
\text { registered and volunteer } \\
\text { (unpaid) nurses. }\end{array}$ & $\begin{array}{l}\text { In } 1921 \text { there were } \\
\text { Damas Enfermeras } \\
\text { de La Cruz Roja } \\
\text { (Ladies Nurses of } \\
\text { the Red Cross) in all } \\
\text { Spanish provinces }\end{array}$ \\
\hline 1917-2010 & Barcelona & $\begin{array}{l}\text { Escola Universitària } \\
\text { d'Infermeria Santa Madrona } \\
\text { (Nursing School St. } \\
\text { Madrona). }\end{array}$ & $\begin{array}{l}\text { Initially a 2-year } \\
\text { program (161 } \\
\text { students) }\end{array}$ \\
\hline $1919-1923$ & Barcelona & $\begin{array}{l}\text { Escola Especial d'Infermeres } \\
\text { Auxiliars de la Medicina, } \\
\text { established by the regional } \\
\text { government. }\end{array}$ & $\begin{array}{l}2 \text { years. Closed } \\
\text { during the Primo de } \\
\text { Rivera Dictatorship }\end{array}$ \\
\hline $\begin{array}{l}1924-\text { to } \\
\text { today }\end{array}$ & Madrid & $\begin{array}{l}\text { Escuela Nacional de Sanidad } \\
\text { (National Health School) }\end{array}$ & $\begin{array}{l}\text { Established links } \\
\text { with the Rockefeller } \\
\text { Foundation, } \\
\text { (fellowships for } 14 \\
\text { nurses and a } \\
\text { midwife between } \\
1931 \text { and 1936) }\end{array}$ \\
\hline $\begin{array}{l}\text { 1929-to } \\
\text { today }\end{array}$ & Santander & $\begin{array}{l}\text { Escuela de Enfermeria de la } \\
\text { Casa de Salud de Valdecilla } \\
\text { (School of Nursing of } \\
\text { Valdecilla) }\end{array}$ & $\begin{array}{l}2 \text { years. The } \\
\text { students lived at the } \\
\text { school. }\end{array}$ \\
\hline $1931-1936$ & Barcelona & $\begin{array}{l}\text { Escola d'Infermeres de la } \\
\text { Generalitat de Catalunya } \\
\text { (School of Nursing of the } \\
\text { Government of Catalonia, } \\
\text { Spain) }\end{array}$ & $\begin{array}{l}2 \text { years. The } \\
\text { students lived at the } \\
\text { school. }\end{array}$ \\
\hline
\end{tabular}


the Faculty of Medicine in Madrid. In 1934 the Visiting Nurses Professional Association, presided over by Mercedes Milá Molla, had 109 members. ${ }^{35}$ At the end of November 1936, the number of nurses in the official College of Nurses of Catalonia, a region of Spain, was approaching five hundred. Between 1929 and 1936, 16,366 students in Catalonia applied to have their qualifications recognized. These included the three categories of nurse - nurses, practicantes, and midwives. In all 4,411 licenses were issued: 3,014 practicantes, midwives 721 , and 676 nurses. ${ }^{36}$ In addition to these formally licensed nurses under the Republic's new national provisions for title recognition, there was also an unknown number of nursing professionals who were covered under the Moyano Law (1857), which was still in effect for all three categories of nurse who had held their title since 1915 .

By the 1930s, these modern nursing programs included instruction on public health nursing. Spain, like many countries around the world, was influenced by the rise of the American model of the public health nurse whose main role was to work with communities and families. ${ }^{37}$ This new nurse was an educator and a change agent. Nurses on the left in the United States, such as Lavinia Dock and Lilian Wald and their colleagues in the settlement movement, set out to build supportive communities and promote health among the poorest and most vulnerable members of society. This early 20th-century movement, energized by the end of World War I and the influenza pandemic, was still gaining momentum in the United States and Canada in the 1930s and the nursing leadership in the United States, with the support of the Rockefeller Foundation, saw it as a key advance for both society, in terms of addressing the twin ills of ignorance and poverty, and for the nursing profession, as it provided an autonomous and authoritative community role for nurses independent of medical supervision and hospital hierarchies.

Nursing schools in Spain followed medical schools in the implementation of training programs for well-educated nurses with a strong foundation in public health, health education, and disease prevention. This was the pattern in the United States and Canada, no less than in Spain, and by the mid-1930s the numbers of training centers for nurses run by the Cruz Roja or by universities attached to medical schools had multiplied. At the same time, the older nursing schools based at the hospitals conducted by religious nurses continued to educate nurses who could qualify to meet the national requirements for credential recognition as trained nurses. As in other countries, there was a range of quality in such programs from the country's best and most innovative hospitals, to those with poorer standards of care.

So, despite the lack of precise numbers on trained nurses in Spain before the war, we can be confident that there were many thousands of secular nurses 
who were both trained and held the authorized title of nurse, practicante, or midwife. We can also say with certainty is that neither the Nationalist nor the Republican side had sufficient nurses, secular or religious, to meet demand at the beginning of the war.

\section{Part 2: Spanish Nursing During the War}

Although nursing in Spain had been evolving and progressing in line with peer countries during the first three decades of the 20th century, all of this was to come to an abrupt end with the commencement of the Civil War. As government and rebel forces split the country along battle lines, the lives of religious nurses came under threat in government-held territory and many fled to nationalist held regions. This alone would have constituted a major catastrophe for the provision of hospital care in the country but it was only the beginning. It was impossible to fill the gap made by the departure of religious nurses with fully trained secular nurses. Even before the war there had been insufficient nurses to meet national needs and the ambitious health program of the government had already deployed many nurses to its short-lived community programs. Gauging the number of nurses during the war on both sides is a challenge. However, in the Nationalist or Francoist zone, we have an idea of the overall number of nurses as the war progressed as a result of the issuance, in May 1938, of identity documents for 12,307 nurses and nurse assistants. ${ }^{38}$ On the Republican side, we need to rely on first-person accounts such as those of Gaston Levale, referring to Barcelona, who wrote: "There were 1,000 doctors, 3,200 nurses, 330 midwives and six hundred dentists, working well and imaginatively." 39

The chaos and disruption of Civil War meant that there was a desperate shortage of trained nurses. Both sides responded to this situation by the creation of short specific programs for war nurses. On the Republican side, a system of nurse training was established through trade unions and women organizations. ${ }^{40}$ On the Nationalist side, they prepared military nurses, as Phalanx or the so-called Margaritas. The Cruz Roja trained nurses on both sides of the conflict ${ }^{41}$ (see Figures 3 and 4). Martin and Ordonez describe how politically affiliated models of nursing burgeoned during the war, identifying nursing work as an opportunity for women to engage in the political life of the war.

Different models of nursing coexisted on the Republican side oriented by the political values, such as those of the Anarchists, of Trotskyists, of communists and of liberals and even on the Francoist side, included simultaneously royalist and Falangist women and others who supported traditionalist ideologies. ${ }^{42}$

Over the course of the war three types of Spanish nurses were introduced: qualified nurses (or the equivalent as registration is not a term used in Spain), 


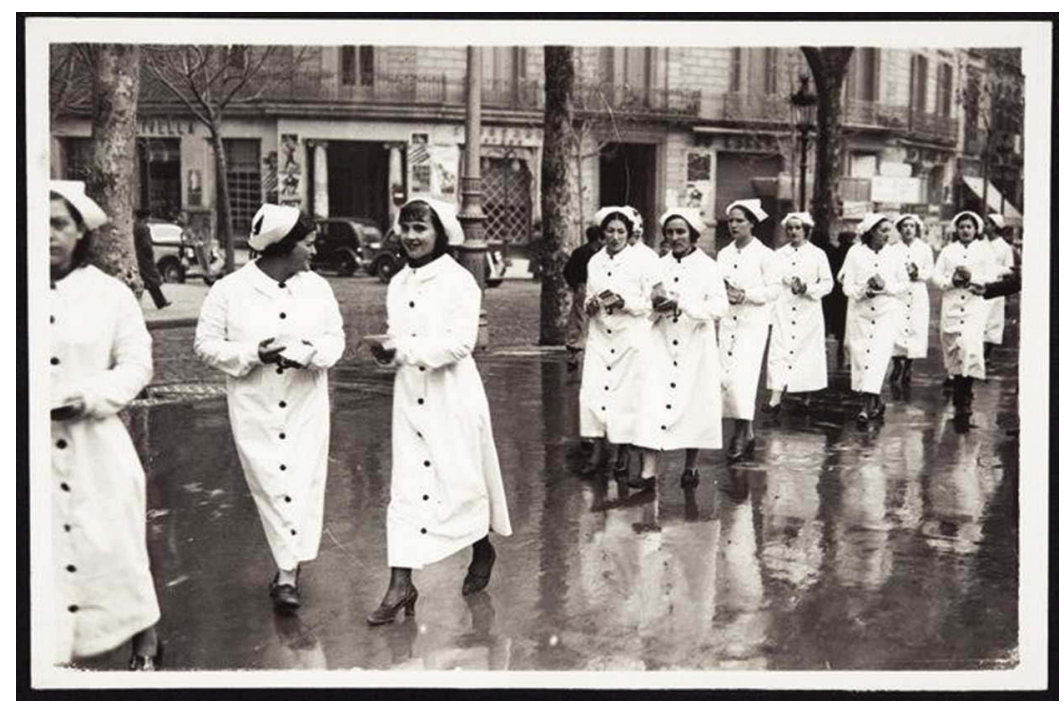

Figure 3. A row of nursing students walking down a street. Probably in Calle Cortes (Today Gran Vía de les Corts Catalanes, 690). Calle Cortes housed a training center for infermeras de guerra of the Free Women of the FAI (Iberian Anarchist Federation). Barcelona, probably winter 1936-37. Photographer Pau Lluis Torrents (National Library of Spain, with permission of the Torrens family).

nurses with "titles of war," or infermeras de Guerra, who were graduates of union or women organization's short training programs (a few months), and nursing aides or assistants (no training). Occasionally, individuals - Spanish and foreign - without any preparation in nursing volunteered to help the wounded and sick as nursing assistants. On the Republican side, writers, artists, photographers worked as these type of nurses with the IBs. ${ }^{43}$ On both sides, Spanish nurses who wished to have their qualifications upgraded from infermera de guerra to nurse, underwent further training programs and additional examinations in order to receive their official nursing certification. ${ }^{44}$

An important collection of essays, Enfermeras de Guerra, edited by Anna Ramio and Carmen Torres, published in Spanish in 2015, sets out the war experience of thirteen Spanish nurses. ${ }^{45}$ The work is divided into sections distinguishing between nurses who qualified before the war, nurses who underwent training during the war as infermeras de guerra, and did not continue as nurses at the end of hostilities, and nurses who commenced training during the war and continued in the profession afterward. The women were interviewed by a team of researchers as part of an extensive oral history project on nursing during the war. The research highlights the diversity of backgrounds, 


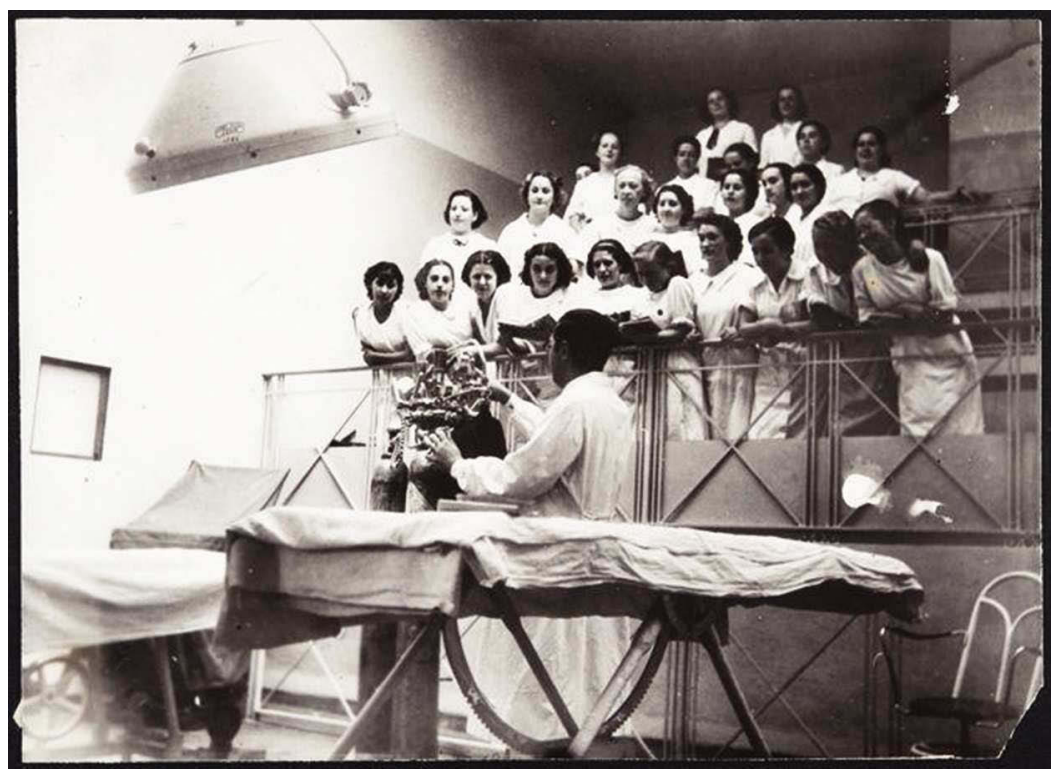

Figure 4. A group of 26 students attending a practice class. Probably Barcelona. 19361939. Reprinted with the permission of the National Library of Spain.

religious and political affiliations, education pathways, and subsequent lives of these women. It also highlights the wide range of work they undertook during the war, the diversity of training and mentorship provided and how the experience impacted their future. The women interviewed worked in major hospitals in Barcelona, in rural areas, in maternal and infant care, surgery, tuberculosis, anesthetics, and multiple other areas of practice.

Some of the most important insights and recollections provided by Ramio, Torres, and colleagues deal with the transitions at the beginning and end of the war. These nurses describe the extraordinary effort to fill the gap made by the loss of so many religious nurses with the commencement of hostilities, and the vital contribution of those nuns (in civilian dress and at great risk) who remained in Republican-controlled areas in training the vast numbers of women who responded to the radio call for volunteers to staff the hospitals and clinics (see Figure 5).

Much was accomplished in those first months of the war when the Republican side needed to establish an entire military medical infrastructure of advanced and rearguard hospitals. The lack of pre-existing infrastructure led to creative innovations, such as the mobile operating clinics (see Figure 6), and the mobile blood service that the Republican medical teams became famous 


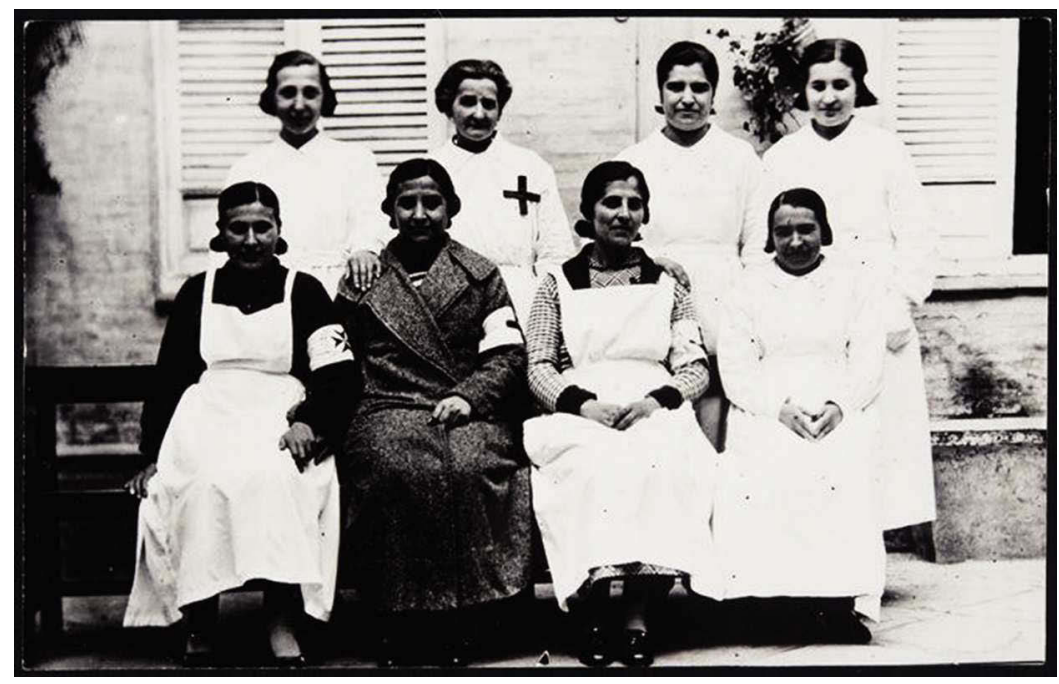

Figure 5. Group of eight women. Text on the back of the photograph translates as: Old Carmelite nuns, today nurses of the hospital of Andújar. Andújar (Jaén, Spain) 1936-1939. Reprinted with the permission of the National Library of Spain.

for during the war, and were widely imitated in World War II. The transition at the end of the war, when the Nationalist forces took control, was another chaotic time. Although Spanish doctors and nurses were among the thousands of exiles who departed under fire to France, many others held to their posts and continued to work as the religious nurses took back control of the health institutions across the country.

Further insight into the world of nursing during the war can be found in Shining Beacons in the Darkness: Memories of Saving Lives during the Spanish Civil War in Catalunya. ${ }^{46}$ Published in 2013 in Catalan and English by Del Memorial Democratic Generalitat de Catalunya, this work is combination of first person and scholarly accounts of the healthcare and aid by doctors, nurses and emergency workers, general citizens and foreigners during the war, the very great dangers they faced both not only from the war directly, but from their Republican colleagues should their loyalties ever be suspect.

One ugly challenge of Civil War that affected the availability of skilled nurses and doctors was the difficulty in distinguishing enemy from friend. The catastrophic shortage of nurses on both sides ${ }^{47}$ was exacerbated by the debugging of "politically suspect" civilian nurses. Depuradas was the term for nurses and doctors in the Francoist area who were unable to practice because they were considered politically suspect. On both sides of the conflict, there were 


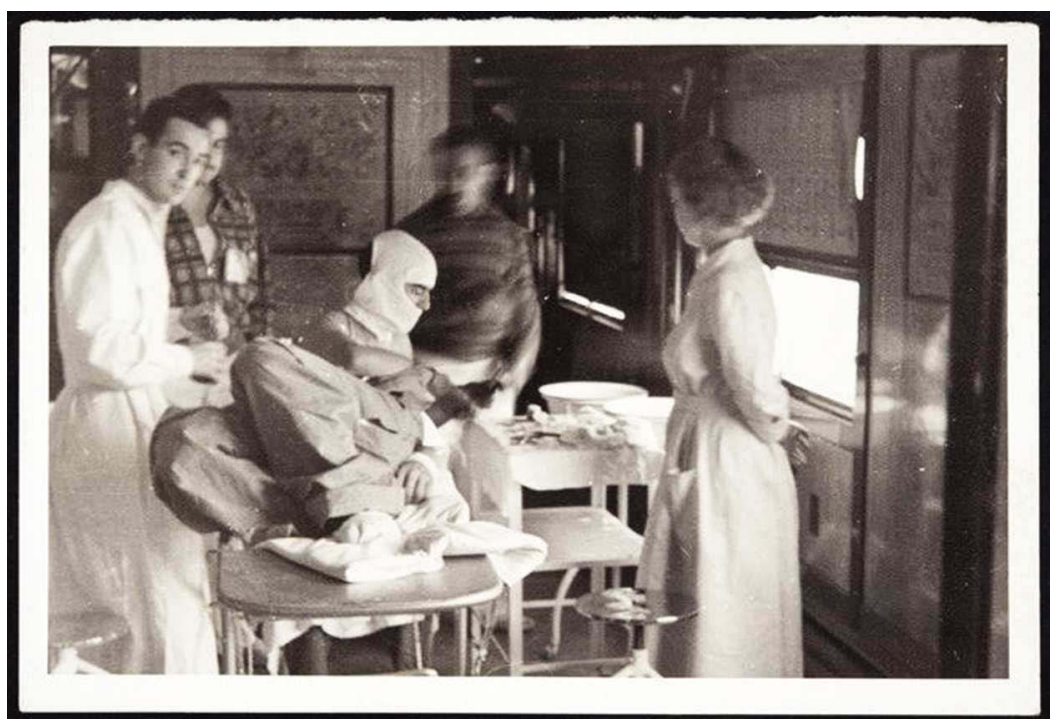

Figure 6. Inside one of the treatment rooms where surgeons and nurses attended to the wounded on a hospital train. Unknown place, probably 1936-1937. Photographer Centelles. Reprinted with the permission of the National Library of Spain.

harsh measures for spies or fifth columnists, and this vigilance and paranoia played out in every workplace, community, and sector throughout the country. In fact, nurses suffered greatly in this climate of suspicion because of their access to the battlefront and to wounded men who may inadvertently reveal classified information. On both sides, courses for nurses were introduced that included ideological indoctrination and nurses had to demonstrate political correctness to be permitted to work.

Republican nurse Ana Pibernat Caner's memoir is rich in its detail of front line service and typhoid fever nursing. ${ }^{48}$ Pibernat was a graduate of the nursing program in Girona where she completed primary studies and 2 years of nursing, achieving her license just before the commencement of the SCW. She was one of the growing number of graduates from newly established schools of nursing under the Second Republic, which were committed to public health and in which the nursing profession was considered a major resource in their programs for improvement of health in the population, with nurse-led community health programs. ${ }^{49}$

During the war, Pibernat volunteered to the front line hospital located in a train tunnel between Flix and Asco (Tarragona). She was also at the hospital at Valls during the typhoid epidemic and at the end of the war participated in 
the evacuation of the wounded during the retreat: "from hospital to hospital" to Figueras at the French border. ${ }^{50}$ Trinidad Gallego Prieto, like Pibernat, was an experienced and qualified nurse who had worked under the Second Republic before the war. ${ }^{51}$ Gallego was also a midwife and she had been actively involved in implementing the Republican government's reforms of maternal care which shifted the model from punitive to supportive care for unmarried pregnant women and new mothers. During the war, she was the head nurse at the Hospital Clinico de San Carlos de Madrid which attended wounded military and civilian patients.

Only one nurse of the thirteen profiled in the collection by Ramio and Torres matches the profile of the willing "chicas" described in so many of the recollections of the brigadists. Maria Sans Moyer, an infermera de guerra, was stationed at a brigadist hospital and was trained by a British IB nurse. ${ }^{52}$ She spent the war entirely with brigadist forces and was a veteran of the Battle of Ebro. In fact, Maria Sans Moyer is believed to be the inspiration for Hemmingway's character Maria, in For Whom the Bell Tolls. ${ }^{53}$

If Sans Moyer exemplifies the nurse who is the subject of so many firstperson accounts by IB volunteers, Trinidad Gallego Prieto and Ana Pabernat typify the new nurse of the Second Republic seldom encountered by the volunteers. These nurses were well educated and professional, had a strong commitment to justice and saw the important role the nursing profession had to play in the reform and democratization of society. ${ }^{54}$ They also typify the kind of nurse that the dictatorship was determined to eradicate. The defeated Second Republic had aligned a feminist reform agenda and the public health agenda. They had recognized the potential for women to play a major part in their social reform program both as leaders and workers, and nursing and midwifery were key to the implementation of these reforms which directly affected women and children. Following the war, the public health programs that had been central to the Republic's reform platform were abandoned.

\section{Part 3: The Aftermath}

As the defeat of the Government forces became more certain, the IBs formally withdrew. This was a terrible time for the volunteers and for the nursing and medical teams there was the additional trauma of abandoning not just colleagues and comrades, but patients. And as Europe descended into World War II many of the volunteers found the door home closed behind them. The false documents and illegal border crossings, which had been necessary to enter Spain, made the return journey particularly difficult. For those volunteers from 
countries with fascist Governments, there could be no return for "red" volunteers. This was especially the case for those of Jewish ancestry. ${ }^{55}$

For the defeated Spanish Republicans, the situation was also desperate. Following the exodus under fire of tens of thousands of Spanish refugees to France. Internment camps were established by the French government. These camps had appalling conditions and accompanying high death rates from disease and exposure. Foreigners and Jews were handed over to the Gestapo following the German invasion of France in 1940. This was the fate of Austrian IB volunteer Auguste Guttman, a nurse veteran of the Great War. Guttman had arrived in Spain in August 1937 and remained until the evacuation of Catalonia, a Republican stronghold, working at the Hospital at Villaneuva de la Jara. She is believed to have died in Auschwitz. ${ }^{56}$ The exiled nurse Aurora Fernández also left testimony of this hardship and human tragedy in her unpublished memoirs. ${ }^{57}$

Those who remained in Spain risked fierce retribution. In the violence and recrimination that followed the Civil War, the experience of these doctors and nurses very much depended on their political profile during the war (and that of their families), and on luck. For some, the transition was very challenging but in the end they simply kept working, for others there was no possibility of continuing their work as doctors and nurses. Republicans who survived torture and imprisonment were forbidden to practice in their professions and many were forced into exile. ${ }^{58}$ Republican nurses faced humiliation as a "red" women, along with the suspension of their nursing licenses under the Francoist regime. ${ }^{59}$ The young Spanish women who had been trained by the IB nurses at improvised auxiliary nursing units at the hospitals were accused of collaboration with the reds. They were prohibited from taking advantage of the knowledge and skills they had learned as auxiliaries of foreign nurses, unable to work as nurses after the war.

In February 1939 Ana Pibernat, along with four other nurses and an abandoned child crossed the Pyrenees. She returned to Spain in 1940 but was forced to escape from her village to avoid violent retribution. Her nursing license was invalidated under Franco and she was unable to gain permission to take the new exam as several of her family members were in prison during the early years of Franco's dictatorship. Trinidad Gallego was imprisoned at the end of the war, along with her mother and grandmother, and in and out of jail a total of sixteen times. Each time she provided nursing and midwifery care to the women and children in the jails. It was not until 1969, 30 years after the war, that she was once again permitted to work as a nurse and midwife. ${ }^{60}$ Infermera de guerra, Maria Sans Moyer also fell victim to the persecution of "reds" 
that followed the war. With her father and brother in prison and her sister in Argentina, San Moyer was forbidden from continuing in nursing. ${ }^{61}$

Unlike the boost in professional standing for nursing that took place post World War II in the Allied nations, nothing remained of the high levels of nursing skill and innovation practiced by the international nurses and their colleagues in Spain. In fact, professional nursing took a backward step following the defeat of the Republic. ${ }^{62}$ During the postwar period jobs for nurses in hospitals, once again under the control of the Catholic Church and managed by religious sisterhoods, were preferentially granted to the minimally trained infermeras de guerra, on the Pro-Franco side. In this way, many nurses with little education managed to enter the profession. At the same time curricula that paid attention to primary healthcare, public health or community care, or any specializations such as were advanced by nurses under the Second Republic, were abandoned for decades. ${ }^{63}$

Following the war, nurses who had qualified during the pre-war period were required to have their credentials reviewed, perhaps reexamined, and to obtain a certificate of good conduct. ${ }^{64}$ And for the Republicans who remained or returned to Spain during the Franco years, many sacrificed the possibility of working as registered nurses, as they refused to undergo the humiliation of reexamination and "Social Service" compulsory for women aged 17 to 35 years. The latter was a means of control and immersion in the Francoist ideology and obligatory for women, the equivalent of national service for men, prior to applying for any official documentation such as a passport or driving license.

With the victory of conservative forces, the reformist agenda of the Republic was turned back and its nascent initiatives eradicated, along with the programs that supported contraception and gave women significant rights for divorce and custody of children. The professionalized, university educated, public health-focused professions of nursing and midwifery were considered suspect and antithetical to the values of the church and patristic state under Franco.

In the decades following the war, as the turmoil of transition and rebuilding hospitals and healthcare began, there was a clear need for significant reform of the system. Like the Republic before it, the Dictatura needed to modernize its systems and to improve the education and skill of the health workforce to meet the needs of 20th-century healthcare. Furthermore, because of the complexity of the postwar period which facilitated the integration of infermeras de guerra, on the victorious nationalist side, and excluded so many qualified nurses who had been in the Republican sector, the level of knowledge and skill among nurses was no longer standardized until 1953. 
As Siles argues with respect to both Spain and Latin America, authoritarian or dictatorial regimes with their emphasis on conservative patriarchal values, result in diminished professional status for nursing. ${ }^{65}$ Not only were republican or suspect nurses banned or forced to undergo ideological based training, but the profession itself became the target of social reengineering under Franco. In 1953, the dictatorship responded to the demands of hospital development and expansion to reform the education and professional standing of nurses. The previously distinct categories of nurses: midwives (matronas), practicantes, and nurses (enfermeras) were consolidated into a single program and certification process under a new title. In 1953, the titles of "nurse" (enfermera) and "midwife" (matrona) were downgraded to "Assistant Health Technician" (Ayudante Técnico Sanitario, ATS), a title that was highly unpopular with the majority of nurses and midwives and yet remained in place until 1977 after the death of Franco. Students of ATS were divided by gender. Female students attended training schools with mandatory boarding, and the curriculum was specifically oriented by gender to reflect the values of the patristic state. ${ }^{66}$ The ATS program did succeed in raising the entry requirements from the postwar low and improved the level of preparedness of the hospital workforce. However, it also made clear that the sole aim of these new health workers was to be auxiliary to and a support for medicine. ${ }^{67}$ Under the close direction of the Women's Section of the Falangist Party, the Church, and the medical profession, nursing education was stripped of all professionalizing sentiments and infused with the patristic values of the regime and devoted to subservience to medicine and the Catholic state. ${ }^{68}$ Nursing had to wait until the death of Franco to reemerge as a full profession under the titles of nurse (enfermera) and midwife (matrona) once more. With the passing of the dictator, all nursing studies were instated at the University level as Diplomados en Enfermeria (Nursing Diplomates; See Table 1).

\section{Conclusion}

The scholarly renaissance in interest in the SCW in the 80 s and 90s, particularly from British and American historians, led to a surge of publications on the topic of the war and the role of brigadists - men and women.

One of the casualties of this narrative was the story of Spanish nurses. The grim portrayals of the conditions of Spanish hospitals have been taken as reflective of the actual state of Spanish nursing, rather than the state of volunteer nursing in wartime. Such views have reified foreign expertise at the expense of 
their Spanish colleagues and shaped both the internal and the external view of the profession and healthcare in Spain prior to the war.

The story of nursing in Spain during the war is a complicated history that divides republican and nationalist sides. The Catholic Church had long played a central role in Spanish society and in the postwar period it regained a strong presence in education and healthcare. What the IB nurses and volunteers witnessed during the chaos of the Civil War was a profession sundered by pro and anti-clerical ideologies at war. The Civil War ruptured the profession with the losers the secular, university educated public health nursing movement which took some 50 years to recover.

Given this subsequent course of events, we argue, it is indeed worth understanding both the context and impact of the apparent absence of professional nursing and skilled nurses during the SCW by the very many writers from all over the world who have written on the war. It seems that Catalan nurse Ana Pibernat was correct when she lamented "We are the nurses no-one remembers." 69 Under Franco such remembering was forbidden. Under the Pact of Oblivion it was discouraged. Only now, as so many of the nurses are gone, are their stories beginning to surface and nursing under the Second Republic, that important period in Spanish nursing history, can become part of the narrative of nursing and of women in 20th-century Spain.

Notes

1. Ana Pibernat, "Ana Pibernat Caner. Mis Memorias," in Memorias del Pueblo, ed. Amparo Hurtado (Barcelona, Spain: RBA, 2004), 37-63.

2. The Franco dictatorship did not represent a homogeneous period. There were several stages: The first between 1939 and 1950, characterized by extreme repression and international isolation, the second between 1951 and 1965 characterized by greater international support, and the third between 1966 and 1975 (Tardofranquismo) characterized by economic development and opening. See Javier Tusell, "La Dictadura franquista," in Historia de España, ed. John Lynch, vol. XIX (Madrid, Spain: El País, 2007). For a general and classic text on the war, widely read both within Spain (although banned during the dictatorship) and throughout the world see Hugh Thomas, The Spanish Civil War (New York: Harper and Row, 1961), 616. About the civil war from broad perspective see Paul Preston, The Spanish Civil War: Reaction, Revolution, and Revenge. Revised and Expanded Edition (WW Norton \& Company, New York, 2007); Raymond Carr, The Spanish Tragedy: the Civil War in Perspective (Phoenix Press, London, 2000). For Spanish literature see Julián Casanovas, "Sólo en Espańa hubo guerra civil," El País, Madrid, July 17, 2011, http://elpais.com/diario/2011/07/17/domingo/1310874758_850215.html; Angel Viñas, El Combate por la Historia. La República, la Guerra Civil, el Franquismo (Barcelona, Spain: Pasado \& Presente, 2012). 
3. The Pacto de Olvido, or the Pact of Forgetting, in English was an agreement among the political parties to assist in the transition to democracy at the end of the dictatorship. Legally underpinned by the Spanish Amnesty Law of 1977 it prevents the prosecution of war crimes during the war or under Franco's rule. See Madeleine Davis, "Is Spain Recovering its Memory? Breaking the 'Pacto de Olvido," Human Rights Quarterly 27 (2005): 858-80.

4. Francisco José Romero Salvadó, "Killing the Dream: The Spanish Labyrinth Revisited, 1989-1939," in Looking back at the Spanish Civil War. The International Brigade Memorial Trust, Len Crome Memorial Lectures, 2002-2010, ed. Jim Jump (London, UK: Lawrence \& Wishart, 2010), 48.

5. Martha A. Ackelsberg, Free Women of Spain: Anarchism and the Struggle for the Emancipation of Women (Edinburgh, Scotland: AK Press, 2005), 167; Mary Nash and Irene Cifuentes, Rojas: Las Mujeres Republicanas en La Guerra Civil (Madrid, Spain: Taurus Historia, 2006), 233-47.

6. Antony Beevor, The Battle for Spain: The Spanish Civil War 1936-1939 (London, UK: Weidenfeld and Nicolson, 2006), 91.

7. The nationalities (with more than a thousand fighters) from the highest down were: 8,962 French; 3,113 Polish; 300 Italians; 2,341 North Americans; 2,217 Germans; 2,095 Balkan; 1,853 British; 1,722 Belgians; 1,066 Czechs. Michel Lefébvre and Rémi Skoutlesky, Les Brigades Internationales. Images Retrouvées (Paris, France: Seuil, 2003), 16.

8. Oscar Telge, "Prólogo," in Nuestra Lucha Contra La Muerte. El Trabajo del Servicio Sanitario Internacional, ed. Jirku Gusti (nickname Augusta Franciska Stridsberg; no editorial data, 1937), 8 .

9. Report on the Medical Service of International Brigades dated in Barcelona on 26 November 1937, Archivo del Servicio Histórico Militar, Madrid, Spain, (file 1265, Folder 11). Quoted by Jesús Bescos Torres, "Las enfermeras en la Guerra de España (1936-1939)," Revista de Historia Militar 26 (1992): 97-143.

10. Gloria Gallego-Caminero et al., "La Historiografía Sobre Las Enfermeras en Las Brigadas Internacionales (1936-1939). Una Revisión Sistemática.” Poster presented at ICN Conference and CNR, La Valletta, Malta, May 2011; Gloria Gallego-Caminero et al., "75 Years Later. International Solidarity: Nurses of the International Brigades in The Spanish Civil War (1936-1939)." (Oral presentation, Internacional Nursing History Conference, Kolding, Denmark, August 12, 2012; Gloria Gallego-Caminero, "Al Servicio de las Ideas. Religiosas y militantes," in Al servicio de las ideas. La Enfermería en los Procesos Populares de Liberación en Iberoamérica, ed. Beatriz Morrone (Mar del Plata, Argentina: Ediciones Suárez, 2013), 199-234; Sioban Nelson and Gloria Gallego-Caminero, "Beyond the Fiction and Myths: Revisiting the Question of Nurses and Nursing in the International Brigades of the Spanish Civil War (1936-1939)." (Oral presentationat 32nd Annual AAHN Nursing \& Health Care History Conference, Dublin, Ireland, September 17-20, 2015); Gloria Gallego-Caminero, Sioban Nelson, and Paola Galbany-Estragues, "Enfermeras internacionales en la Guerra Civil española (1936-1939)," in Libro del XIV Congreso Nacional y IX Internacional de Historia de la Enfermería. Un siglo cuidando a la sociedad. Centenario del reconocimiento oficial de la Enfermería en España, eds. M. L. Fernández, A. C. García Martínez, and M. J. García Martínez (Santander, Spain: Colegio de Enfermería de Cantabria, Universidad de Cantabria, 2015), 347-52.

11. Mary Birgham de Urquidi, Misericordia en Madrid (México: Costa-Amic, 1975); Lini de Vries, Up from the Cellar. An Autobiography (Minneapolis, MN: Vanilla 
Press, 1976); Judith Keene, The last Mile to Huesca: An Australian Nurse in the Spanish Civil War (Kensington, Australia: South Wales University Press, 1988), Published in Spanish: Judith Keene and Victor Pardo Lancina, eds, Agnes Hodson, A una Milla de Huesca. Diario de una enfermera australiana en la Guerra Civil Española (Zaragoza, Spain: Universidad de Zaragoza, 2005); Penelope Fyvel, English Penny (Devon: Arthur H. Stockwell Ltd., 1992); Angela Jackson, For Us It Was Heaven, Published in Spanish: Angela Jackson, Para nosotros era el cielo. Pasión dolor y fortaleza de Patience Darton: de la guerra civil española a la China de Mao (Barcelona, Spain: Ediciones San Juan de Dios Campus Docent, 2012); Mark Derby, Petals and Bullets Dorothy Morris New Zealand Nurse in the Spanish Civil War (Brighton, Chicago, Toronto: Susex Academic Press, 2015).

12. Jim Fyrth, The Signal was Spain. The Spanish Aid Movement in Britain, 1936-39 (London, UK: Lawrence and Wishart, 1986); Frances Patai, "Heroines of the Good Fight. Testimonies of U.S. Volunteer Nurses in the Spanish Civil War, 1936-1939," Nursing History Review 3 (1995): 76-104; Nicholas Coni, Medicine and Warfare. Spain, 1936-1939 (New York: Routledge, 2008), 31-33; Maria del Carmen Pérez-Aguado et al., ““Medicine and Nursing in the Spanish Civil War: Women Who Served in the Health Services of the International Brigades (1936-1939)," Vesalius: Acta Internationales Historiae Medicinae (2010): 29-33; Linda Palfreeman, ;Salud! British Volunteers in the Republican Medical Service during the Spanish Civil War, 1936-1939 (Brighton, UK: Sussex Academic Press, 2012); Angela Jackson, British Women and the Spanish Civil War (Abingdon, UK: Routledge, 2002); Walter J. Lear, "American medical support for Spanish Democracy, 19361938," in Comrades in Health: U.S. Health Internationalists, Abroad and at Home, eds. AnneEmanuelle Birn and Theodore M. Brown (New Brunswick, NJ: Rutgers University Press, 2013), 65-81; Anne-Emanuelle Birn and Theodore M. Brown, "Across the Generations: Lesson from Health Internationalism," in Comrades in Health: U.S. Health Internationalists, Abroad and at Home, eds. Anne-Emanuelle Birn and Theodore M. Brown (New Brunswick, NJ: Rutgers University Press, 2013), 303-18.

13. George Orwell, Homage to Catalonia (Middletown, DE: Dogstail Books, 2015), 145.

14. "Annie Murray Obituary," The Herald Scotland, 4 December, 1996. www.heraldscotland.com/news/1n.d.052.Annie_Murrie/. The documents have both her English and Scottish (Murrie) name listed. Accessed 11 June, 2019.

15. Jackson, For Us It Was Heaven, 27. This quote has been much cited. Originally this very critical assessment of the religious nursing sisters came from Roser Valls, ed., Infermeres catalanes a la Guerra Civil espanyola (Barcelona, Spain: Edicions Universistat de Barcelona, 2008), 23. The Valls quote presents the testimony of a Communist Party nurse who (perhaps unsurprisingly) paints an unflattering picture of religious nurses. This same quote turns up in Palfreeman's book. Linda Palfreeman, Aristocrats, Adventurers and Ambulances. British Medical Units in the Spanish Civil War (Brighton, Chicago, Toronto: Sussex Academic Press, 2015).

16. Ruth Wilson, Radio Speech from Madrid on January 10, 1938 (Marx Memorial Library Box D-2: A / 1). Identifying the IB nurses is challenging. For instance Ruth Epstein appears in the sources as a Canadian and an American, as Jewish and as married to a Jewish man, under the names of Esther and Ruth, Wilson and Epstein. According to Francisco Guerra she was Esther WILSON (1906-1996), a single woman born in Toronto, Canada. She was a registered nurse who in 1934 married Jake Epstein, who also came to Spain. She arrived May 29, 1937. After joining the IB she was appointed sergeant, head nurse of 
the "Centro" hospital in Murcia, from there she went to the "Universidad" hospital and finally to the "Red House" hospital. She was evacuated in April 1938 to the Hospital de Mataró, Barcelona, from there to Vich, Barcelona and repatriated in August in 1938. She died in New York. Francisco Guerra, La Medicina en el exilio republicano (Madrid, Spain: Universidad de Alcalá, 2003), 508.

17. Jackson, For Us It Was Heaven, 28, 30, 46. Jackson does allow that the Catalan government "Began an Ambitious Project for Training Nurses, the First School Having Opened in Barcelona in 1933," 27.

18. However, Darton is full of admiration for the innovative Catalan surgeons, especially Moises Broggi and Josep Trueta. Jackson, For Us It Was Heaven, 53.

19. Fyrth, The Signal was Spain, 45.

20. Palfreeman, Aristocrat Adventurers and Ambulances, 155.

21. See for background and quality of the work of the nuns in Spain Gloria GallegoCaminero, "Celebrando un centenario más allá de los mitos," in Centenario Enfermeria, 17 Diciembre 2015, ed. Pilar Almansa (Murcia, Spain: Universidad de Murcia, 2015), 11-27.

22. One of the most important medical advances that occurred in the GCE and later had a widespread use in the Second World War was the use of blood transfusion from bottled and refrigerated blood. The world's first preserved blood-transfusion service was created by the health services of the Republican side in Barcelona (August 1936-January 1939) and directed by Federico Duran Jordà who managed to get 28,900 donors and prepare 9,000 liters of blood for donations). He pioneered the development of field transport to the front of refrigerated blood for transfusions. Frederic Duran Jordà, "El Servici de Transfusió de Sang al Front. Organització-utillatge," in La Medicina Catalana. Portaveu de l'Occitània Mèdica Llibreria Catalonia, Barcelona (Abril-maig, 1937), 512-16; Frederic Duran Jordà, “The Barcelona Blood-Transfusion Service," The Lancet 233, no. 6031 (1939): 773-75.

23. The abandoning of patients by the nuns is something of an overgeneralization. Accounts by Spanish nurses also refer to sisters who stayed in place, wore civilian clothes and risked grave danger to stay working in the hospitals. Anna Ramió and Carme Torres, eds., Enfermeras de Guerra (Barcelona, Spain: Ed. San Juan de Dios, 2015), 204; Carles Hervas I. Puyal, "Sanitat a Catalunya Durant la República i la Guerra Civil,” (Tesi doctoral diss., Universitat Pompeu Fabra, 2004). http:// www.tdx.cat/bitstream/handle/10803/7467/tchp.pdf?sequence=1\&isAllowed=y. Accessed 11 June, 2019.

24. The Infectious Hospital of Valencia was installed in the convent of San Cristobal, which was seized from the Canossian Augustinian nuns. It was built at the end of the nineteenth century to accommodate a religious community, not a hospital. When Patience Darton was there it had been transformed into hospital for few months only and while it was likely not a model of neatness and organization, Darton's claims of years of accumulated waste were highly exaggerated. Jackson, For Us It Was Heaven, 33. Another hospital mentioned by Darton was the Pasionaria of Valencia at the Salesian College. It was founded by the Communist Party in November 1936. At the beginning of 1937 it was transformed into the Military Hospital Number 2 with 300 beds. Xavier Garcia Ferrandis and A. J. Munayco, "La evolución de la Sanidad Militar en Valencia durante la Guerra Civil Española (1936-1939)," Sanidad Militar 67, no. 4 (2011): 383-89. http://scielo.isciii.es/pdf/sm/v67n4/historia_humanidades.pdf. Accessed 11 June, 2019.

25. Manuel Álvarez, The Tall Soldier, 40 Years Looking for the Man Who Saved My Life (Toronto, Canada: Virgo Press, 1980), 69. 
26. Isabel Anton-Solanas, Ann Wakefield and Christine Hallett, "International Nurses to the Rescue: The Role and Contribution of the Nurses of the International Brigades during the Spanish Civil War," Japan Journal of Nursing Science 16, no.2 (2019): 103-114. doi:10.1111/jjns.12218.

27. Ibid.

28. See a discussion of the providing care during the war in Documents Del Memorial Democratic, LLums Enmig La Barbàrie Memòries Sobre el Salvament de Vides durant la Guerra Civil a Catalunya (Shining Beacons in the Darkness. Memories of Saving of Lives during the Spanish Civil War in Catalonia; (Barcelona, Spain: Memorial democràtic. Publicacions de la Generalitat de Catalunya, 2013).

29. For a history of the Spanish nursing profession see Carmen Domínguez-Alcón, in Los Cuidados y la Profesión Enfermera en España (Barcelona, Spain: Pirámide, 1986); and in English see Anna Ramió Jofre and Carme Torres Penella, "Nurses: Caring in Times of War," in LLums Enmig la Barbàrie, 297-99.

30. Domínguez-Alcón, Los Cuidados y la Profesión Enfermera en España (Barcelona, Spain: Pirámide, 1986), 308-11.

31. Ibid.

32. Ibid.

33. Rosa Pulido Mendoza, "La Formación de Las Enfermeras de la Cruz Roja Española: Legado Histórico-filosófico." Tesi doctoraldiss, Universidad Complutense, Madrid, 2008).

34. Delores Martín Moruno and Javier Ordónez Rodríguez, "Nursing Vocation as Political participation for Women during the Spanish Civil War," Journal of War and Cultural Studies 2, no. 3 (2009): 305-19.

35. Mercedes Milá Molla was a key figure in Spanish nursing of the period. She received a Rockefeller Foundation fellowships in 1931 and 1936, and attended the program conducted at Belford College, University of London for international nursing leaders. During the Civil War she was the only woman member of the Nationalist general headquarters of Generalisimo, served as President of the Cruz Roja women and was responsible for the management of the General Inspectorate of the Female Hospital Services. Mercedes Milá Nolla, "La mujer en la Guerra: enfermeras," in Los médicos y la Medicina en la Guerra Civil Española, ed. Monografías Beecham (Madrid, Spain: Sanidad Ediciones, 1986), 303-8; Navarro Carballo, "Doña Mercedes Milá Nolla y el Cuerpo de Damas Auxiliares Sanidad Militar. Entrevista del 5 de octubre de 1985," Sanidad Militar 43, no. 2 (1987): 332-36; Nicholas Coni, "The Head of all the Nurses," International Journal of Iberian Studies 22, no. 1 (2009): 79-84; Josep Bernabeu Mestre, Perez Gascón, and Ma. Encarnoción, Historia de la Enfermería de Salud Pública (Publiccaiones de la Universidad de Alicante, Alicante, 1999); Carmen Torres Penella et al., "Relats. Las Enfermeras catalanas en la Guerra Civil española," Temperamentum 6 (2007), http://www. index-f.com/temperamentum/tn6/t2707.php. Accessed 11 June, 2019.

36. Carmen Domínguez-Alcón, Los Cuidados y la Profesión Enfermera en España (Barcelona, Spain: Pirámide, 1986), 120-21; Carmen Domínguez-Alcón, La infermeria a Catalunya (Barcelona, Spain: Editorial Rol, 1986), 26.

37. Bernabeu and Gascón, Historia de la Enfermería de Salud Pública; Cronos, "Cuadernos valencianos de historia de la medicina y de la ciencia," ISSN 1139-711X 3, no. 1 (2000): 219-21. For a discussion of public health and Settlement nursing in the 
United States see Patricia D'Antonio, American Nursing, The History of Knowledge, Authority, and the Meaning of Work (Baltimore, MD: Johns Hopkins Press, 2010), 64-72.

38. José Ramón Navarro Carballo, "Creación y desarrollo del Cuerpo de Damas de Sanidad Militar," Medicina Militar 43, no. 1987, 320-31.

39. Gaston Leval, Le Espagne Libertaire 1936-1939: L'ouvre Constructive de la Revolutión Espagnole (Paris, France: Editions du Cercle, 1971); Cited by Thomas, The SCW, 536.

40. Martín Maruno and Ordóńez Rodríguez, "The Nursing Vocation as Political Participation."

41. Hernández Conesa, Juana María, and Gabriel Segura, López, "La formación de las damas enfermeras de la Cruz Roja durante la guerra civil española (1936-1939)," Index de enfermeria 22, no. 3 (2013): 180-83. For a discussion of the divergent ideologies of the Cruz Roja on the Government and Rebel sides see Maruno and Rodríguez, "The Nursing Vocation as Political Participation."

42. Maruno and Rodríguez, "The Nursing Vocation as Political Participation," 317.

43. Carmen Rivera Villegas, "Otras Miradas Sobre la Guerra Civil Española: Tina Modotti y Elena Garro,” Bulletin of Hispanic Studies 81, no. 3 (2004): 347-60.

44. Valls, Infermeres catalanes, 45.

45. Anna Ramió Jofre et al., Enfermeras de Guerra (Barcelona, Spain: San Juan de Dios, Campus Docent, 2015).

46. Documents Del Memorial Democratic, No. 3, Shining Beacons in the Darkness.

47. Neither were the international volunteers exempt from such scrutiny, one Australian nurse, Agnes Hodson, who was avowedly apolitical came under strong suspicion from a communist compatriot, Mary Lowson, because she spoke Italian and was well educated. Hodson experienced delays in being deployed to the front. Amirah Inglis, Australians in the Spanish Civil War (Sydney, Australia: Allen \& Unwin, 1987), 41, 61. Physicians were subject to the same suspicions. Many of them switched sides when they had the chance.

48. Pibernat, "Mis Memorias."

49. For a discussion of public health in Spain see Rafael Huertas, "Política Sanitaria de la Dictadura de Primo de Rivera a la II República," Revista Española de Salud Pública 74 (2000), http://scielo.isciii.es/scielo.php?pid=S113557272000000600004\&script=sci_arttext, accessed 11 June, 2019; Esteban RodriguezOcaña, Salud Pública en España. Ciencia, profesión y política, siglos XVIII-XX (Granada, Spain: Universidad de Granada, 2005), 12-80; Roser Valls et al., Infermeres catalanes a la Guerra Civil española (Barcelona, Spain: Universitat de Barcelona, 2008), 23; For a discussion of public health nursing initiatives in Spain and the impact of international initiatives on the Spanish context see María Eugenia Galiana-Sánchez, "History of Public Health Nursing in Spain and the International Context," European Journal for Nursing History and Ethics 1 (2019): 124-41.

50. The worst of the bombing was by German aircraft which took place on February 3, 1939 attacking unarmed refugees fleeing to France through a narrow area bounded by the sea and the mountains, 83 people died, of whom 49 adults and 25 children could not be identified. Joan Villarroya, "El Bombardeig de Figueras," in La Guerra Civil a Catalunya 1936-1939, 62nd ed. eds. Josep Maria Solé i Sabaté and Joan Villarroya (Barcelona, Spain: 2005), 766-69. 
51. Roser Valls, "Mas alla de la profesion: Trinidad Gallego Prieto," in Enfermeras de Guerra, ed. Ramió and Torres, (Ediciones San JUan de Dios, Campus Docent, Barcelona, 2015) 177-89.

52. Carme Torres and Roser Valls, "Realidad y ficción: Maria Sans Moyà," in Enfermeras de Guerra, ed. Ramió and Torres, 118-23.

53. Ibid.

54. For a discussion of nursing as a form of political engagement for women during the Republic and the war see Maruno and Rodríguez, "The Nursing Vocation as Political Participation," 305-19; Pilar Díaz Sánchez, "Las enfermeras de Guerra: otra forma de participación política de las mujeres," Temperamentum 2 (2005): 1, http://www.indexf.com/temperamentum/tn2/t0611.php. Accessed 11 June, 2019.

55. Austrian nurse Auguste Guttman had participated in the Great War. She arrived in Spain in August 1937 and remained until the evacuation of Catalonia. She worked at the Hospital of Villanueva de la Jara. Fellow Austrian Anna Peczenik was a nurse at the rearguard hospital in Benicàssim. Both women were murdered by the National Socialists in the concentration camps together with their Spanish Civil War veteran husbands Fritz Guttman and Herman Peczenik. Hans Landauer, Diccionario de Los Voluntarios Austriacos en la España Republicana 1936-1939 (Madrid, Spain: Asociación de Amigos de las Brigadas Internacionales, 2005).

56. Ibid.

57. Aurora Edenhaffer Documents, International Brigades Archives (IBA 29/D/1) in Marx Memorial Library, London.

58. Guerra, La Medicina en el exilio republicano; Encarna Gascón, María Eugenia Galina, and Josep Bernabeu, El Exilio Cientifico Republicanocap. III, ed. Josep L. Barona (Valencia, Spain: Universidad de Valencia, 2010), 99-130; For the situation of exiled midwives see Dolores Rúiz Verdún and Alberto Gomis, "Las Matronas Españolas en El Exilio," Quipu 14, no. 2 (2012): 221-38.

59. Pibernat, "Mis Memorias," 63.

60. Valls, "Mas alla de la profesion," 177-89.

61. Torres and Valls, "Realidad y ficción," 123.

62. Margalida Miró et al., "Spanish Nursing under Franco: Reinvention, Modernization and Repression (1956-1976)," Nursing Inquiry 19, no. 3 (2012): 270-80.

63. Carmen Torres and Roser Valls, "Infermeria durant la Guerra Civil," in Infermeres Catalanes, ed. Valls et al. (1975), 27. The Government of the Generalitat decreed on 12 June 1937 that people with nursing titles acquired through unofficial channels should pass an additional examination in order to receive a certificate of official competition that would replace all other qualifications (diplomas, titles, etc.) obtained. The Social Service was mandatory for all women between 17 and 35 years, for a minimum of 6 months and was organized and tutored by the Sección Femenina de Falange (Female Section of Falange Party, the party that supported the Nationalists). It was a prerequisite for all women who wished to obtain a degree to pursue a career, work in public and private companies, public jobs or get driving license. Nurses were generally exempt from Social Service. It was abolished at the death of Franco in 1975.

64. Pilar Almansa Martínez, "La formación enfermera desde la Sección Femenina," Enfermería Global 7 (2005): 1-11 www.um.es/ojs/index. php/eglobal/article/viewFile/484/468. Accessed 11 June, 2019 ; Anna Ramió Jofre and Carme Torres Penella, "Nurses: Caring in Times of War," in Documents Del Memorial 
Democratic Shining Beacons in the Darkness, 296-310; Carles Hervas I. Puyal, Catalonia's Doctors and the Spanish Civil War (1936-39), Ibid. Both texts includes testimonies from veteran Catalan nurses and doctors from a variety of backgrounds and levels of training.

65. Dr. JoséSiles, Prologo, in Beatriz Morrone (compiladora) "Al Servicio de las ideas," in La Enfermería en los Procesos Populares de Liberación en Iberoamérica, 2nd ed. (Argentina: Ediciones Suárez, 2013), 9.

66. Miró et al., "Spanish Nursing under Franco," 270-80.

67. Ibid.

68. Ibid.

69. Pibernat, "Mis Memorias," 37-63.

Disclosure. The authors have no relevant financial interest or affiliations with any commercial interests related to the subjects discussed within this article.

Sioban Nelson, RN, PhD, FAAN, FCAHS

Professor

Lawrence S. Bloomberg Faculty of Nursing

University of Toronto

155 College Street

Toronto, $\mathrm{ON}$

M5T 1P8, Canada

Paola Galbany-Estragués, PhD

Research Group on Methodology, Methods, Models and Outcomes of Health and Social Sciences (M3O)

Faculty of Health Science and Welfare

Centre for Health and Social Care Research

University of Vic-Central University of Catalonia

C. Sagrada Família, 7, 08500 Vic, Spain

Gloria Gallego-Caminero, RN, BA, PhD

Honorary Collaborating Professor

Department of Nursing and Physiotherapy

University of Balearic Island

Ctra de Valldemosa Km 7,5 Palma, Spain 